\title{
Patterns of Innovation and Knowledge in Two Ethiopian Informal- Sector Clusters: A Study of the Shiro Meda Handloom-Weavers and Merkato Shoemakers
}

\author{
Wondwossen Belete \\ President, Society for Technology Studies (STS), Addis Ababa
}

\begin{abstract}
This article provides findings from a study of innovation and knowledge management practices in two informal-sector micro and small enterprise (MSE) clusters in the Ethiopian capital, Addis Ababa: a handloom-weaving cluster and a shoemaking cluster. The activities in these two clusters were studied in order to explore the patterns of innovation in the MSEs, and to identify factors that influence collaboration and the spread of knowledge among the enterprises. The research also explored the enterprises' knowledge appropriation behaviours and perspectives in relation to their informal-sector innovations, i.e., their orientations towards both informal knowledge appropriation mechanisms and formal tools of intellectual property (IP) protection.
\end{abstract}

\section{Keywords}

innovation, knowledge-sharing, knowledge appropriation, intellectual property (IP), informal sector, micro and small enterprises (MSEs), clusters, Shiro Meda cluster, Merkato cluster, handloom-weaving, textiles, cotton, shoemaking, footwear, leather, Addis Ababa, Ethiopia

DOI: https://doi.org/10.23962/10539/26170

\section{Recommended citation}

Belete, W. (2018). Patterns of innovation and knowledge in two Ethiopian informal-sector clusters: A study of the Shiro Meda handloom-weavers and Merkato shoemakers. The African Journal of Information and Communication (AJIC), 22, 83-109.

https://doi.org/10.23962/10539/26170

\section{Acknowledgements}

The research on which this article is based was carried out under the auspices of the Open African Innovation Research (Open AIR) network, with financial support from Open AIR, the Social Sciences and Humanities Research Council (SSHRC) of Canada, the International Development Research Centre (IDRC), and the UK Department for International Development (DFID). The findings and analysis provided in this article are those of the author, and are not representations of the views of any of the funders. This article draws on the contents of a 2018 Open AIR Working Paper (Belete, 2018) by the same author.

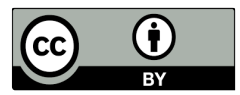

This article is licensed under a Creative Commons Attribution 4.0 International (CC BY 4.0) licence: http://creativecommons.org/licenses/by/4.0 


\section{Introduction}

\section{Background}

Much has been written in recent decades about the importance of innovation for economic growth. Innovation is considered the foundation of competitiveness of firms and a crucial element in the process of improving the long-run economic performance of nations (Dosi \& Nelson, 2010; Fagerberg \& Verspagen, 2002; Freeman, 1982). However, most of the research work on understanding the process of innovation and its relationship to growth and development has been conducted in economically advanced countries, where technological change takes place primarily through research and development that seeks to push the global knowledge frontier further.

In contrast, in developing countries, technological change occurs primarily through adopting and adapting existing technologies. In a developing-country context, technological progress primarily involves gaining mastery over products and processes that have already been put to use in more technologically advanced countries (Chaminade et al., 2009; UNCTAD, 2007; Westphal et al., 1985). This difference demonstrates the importance of understanding the nature of innovation in developing countries - and the importance of using a different lens from that which one would use in innovation studies conducted in more mature economies.

In low-income countries, micro and small enterprises (MSEs), most of which operate in the informal sector, play a crucial role in innovation. These enterprises are also important providers of employment and livelihoods to a large number of the poor. The MSEs are engaged in various innovative activities aimed at contributing to their growth and competitiveness.

The study on which this article is based examined the factors that affect MSE innovation in a low-income country, Ethiopia, through focus on informal MSEs in two informal-sector clusters: a handloom-weaving cluster and a leather footwear cluster. The study findings, as outlined in this article, provide enhanced understanding of the patterns of innovation in Ethiopian MSEs operating in informal settings, and the findings also identify factors that influence collaboration, the spread of knowledge, and knowledge appropriation, by such enterprises.

\section{Objectives}

The objective of the study was to contribute to the current understanding of the processes of innovation and knowledge management in African informal-sector MSE clusters through study of two such clusters in the Ethiopian capital Addis Ababa. Specifically, the study sought to:

- examine the empirical evidence related to innovation in informal MSEs in the two clusters, and identify factors that influence their innovative performance; 
- determine the types of knowledge-sharing mechanisms and interactions among the informal MSEs working in the two clusters; and

- investigate the forms of knowledge appropriation, both informal and formal (including intellectual property (IP) rights protections), being practised in the two clusters.

\section{Methodology}

The study focused on the Shiro Meda handloom-weaving cluster and Merkato leather-footwear manufacturing cluster, both located in the Ethiopian capital city, Addis Ababa. Data were collected through interviews with individuals owning, or employed by, the MSEs in the two clusters, and with government officials. The interviews were conducted using structured interview guides (see Appendices). The interviews with MSE owners and workers sought information on the backgrounds of the MSEs, details about their enterprises, and in-depth information about the enterprises' activities and innovations (in terms of production methods and inputs, product characteristics, and marketing activities). The interview questions also sought to find out about the enterprises' networking and collaboration modalities within their respective clusters, and their methods of knowledge appropriation. The interviews held with government officials focused on government policies, programmes and initiatives which impact on activities of the MSE sector.

Interviews were conducted with 21 weavers in the Shiro Meda cluster, 14 shoemakers in the Merkato cluster, two patent administrators in the Ethiopian Intellectual Property Office (EIPO), a technology transfer director in the Ministry of Science and Technology (MOST), and an expert in the Federal Micro and Small Enterprises Development Agency (FeMSEDA).

All the weavers and shoemakers included in the interview sample were men. The women in the Shiro Meda weaving cluster with whom I could make contact were all engaged in cleaning and spinning of cotton, not weaving. The weaving was found to be predominantly a male job. And in the Merkato footwear cluster, while documents reviewed for this study, and my observations, confirm that women take part in the process of shoemaking in that cluster, my attempts to interview female shoemakers were unsuccessful. In selection of the MSE interviewees, assistance was received from individuals who had acquaintances in the two clusters.

In addition, primary document data on the two clusters were collected from documents published by government offices and other official bodies. I also consulted relevant secondary literature available on the internet: published books, journal articles, and reports. 


\section{The MSE sector in Ethiopia}

\section{Nature and role of MSEs in the national economy}

MSEs play a crucial role in the Ethiopian economy, because of their contributions to gross domestic product (GDP) and their role in poverty reduction and improvement of income distribution. In 2013 MSEs contributed 30\% of the GDP share of Ethiopia's manufacturing industries (MoFED, 2013). More than 70\% of MSEs in Ethiopia were found, in 2003, to be engaged in the following: production of textiles; food and beverage processing; production of leather products, including footwear; and manufacturing of wood and wood products (CSA, 2003). MSEs are also strongly present in the services sector. According to a survey conducted by Ethiopia's Central Statistical Agency (CSA) in 2002-03, a large concentration of MSEs was found in the country's trade, hotel, and restaurant services sub-sectors.

According to the 2011 regulation that established the MSE support agency FeMSEDA, a micro enterprise is defined as an enterprise with: five or fewer employees, including the owner and owner's family members who work in the enterprise; and (for a services enterprise) total capital not exceeding ETB50,000 (approximately USD1,800 in 2018) or (for an industrial enterprise) capital not exceeding ETB100,000 (USD3,600). A small enterprise, meanwhile, is defined as having between six and 30 employees, and capital of ETB50,001 to ETB100,000 (USD1,800 to USD3,600) in the service sector, and ETB100,001 to ETB1,500,000 (USD3,600 to USD54,000) in the industrial sector (FDRE, 2011b).

Urban unemployment and underemployment are serious social problems in Ethiopia. The labour force is growing much more rapidly than the population as a whole, because of Ethiopia's demographic profile, which is characterised by many more young people entering the workforce each year than old people leaving it (FDRE, 2009). Rural-to-urban migration is also increasing, driven by the dwindling amount of farmland available to the rural population and low levels of agricultural productivity. Informal-sector MSEs give the urban poor, unable to find jobs in the formal sector, the opportunity to take part in paid employment activities, to expand their alternatives for supporting their families, and to contribute to national economic development. Furthermore, the MSE sector provides a breeding ground for innovative entrepreneurs.

Many MSEs in the Ethiopian manufacturing sector, especially those grouped under cottage and handicraft industries, specialise in a variety of simple items made by hand. These products, which result from labour-intensive activities, are not easily produced by larger enterprises engaged in mechanised production methods. For instance, the expert in FeMSDA who was interviewed for this study, and some of the handloom-weavers interviewed in the Shiro Meda cluster, mentioned that Chinese enterprises try to produce imitations of Ethiopian traditional clothes at an industrial 
scale but cannot compete with the quality of the clothes produced by the handloomweavers. The interviewees said consumers see the Chinese products as being lowquality, cheap substitutes for the handmade products, giving the local handloomweaving MSEs a competitive advantage in the market.

The MSE sector in Ethiopia is dominated by informal-sector enterprises, and there is a wide range of estimates of the size of the country's informal sector. The wide variations in the estimates would appear to be the result of variances in the approaches followed, in seeking to measure informality, by government agencies, international organisations, and individual researchers. According to a nationwide urban informal-sector survey carried out by Ethiopia's CSA in 2003, the number of people engaged in informal-sector activities was 997,380, of which 799,353 (80.15\%) were enterprise-owners and 198,027 (19.85\%) were persons working under employment agreements (CSA, 2003). This put informal-sector employment at 50.6 $\%$ of total urban employment during the survey period. The survey also found that the majority (51.27\%) of the informal-sector workforce was engaged in crafts and related trades. These craft and related enterprises were found to include: the home-based workshops of traditional artisans in weaving, shoemaking, shoe-repairing, tailoring, hairdressing, carpet-making, pottery, basketry, and embroidery; small maintenance and repair shops for electronics; and enterprises engaged in manufacture and sale of local beverages.

A 2014 CSA survey put the share of urban informal-sector employment within total urban employment at 24.9\% (CSA, 2014). However, some government documents and reports by international organisations put the figure for informal-sector activity in urban Ethiopia at a much higher level. For instance, in the National Employment Policy and Strategy of Ethiopia, it is stated that the informal sector on average accounts for $71 \%$ of urban employment in Ethiopia (FDRE, 2009). (The variations in estimates result, to some extent, from the fact that one can define formality in terms of various characteristics, including company registration, payment of taxes, management structure, contractual arrangements with employees, and market orientation.)

Important to conceptualising the informal sector is cognizance of the realty that informal enterprises typically operate along a continuum, between informality and formality, whereby different activities and actors sit at different locations along the continuum (De Beer et al., 2013; Kraemer-Mbula, 2016; ILO, 2002; Steel \& Snodgrass, 2008). For instance, in Ethiopia, there are a number of informal-sector MSEs that sometimes work for formal enterprises under sub-contracts. Informalsector footwear manufacturers produce some well-known brands of shoes through sub-contract agreements with formalised medium- and large-scale shoe enterprises. And many traditional weavers in the informal sector produce fabrics for fashion designers who operate in the formal sector. The fashion designers then market the 
final products under their own trademarks. Many MSEs have relations with formalsector input suppliers, with service providers, and with wholesalers and retailers of final products.

\section{Government policies}

The first government strategy dedicated to advancing MSE growth in Ethiopia was the federal MSE Development Strategy of 1997 (FDRE, 1997), accompanied by a set of sub-national strategies for the regions. The focus areas of the strategy included: encouraging exploitation of local raw materials; correcting the preferential treatment accorded to bigger enterprises; export promotion; creation of long-term jobs through skills-upgrading programmes; and strengthening the use of appropriate modern technologies. The strategy supported networking of small and fragmented enterprises within sectors, regions, or other localities. In 2011, the government published a revised MSE support blueprint, the Micro and Small Enterprise Development Policy and Strategy, which places emphasis on: enhancing the competitiveness of MSEs; ensuring continued rural development via sustainable growth of MSEs; and making the MSE sector a foundation for industrial development. The revised strategy also prioritises the role of technical and vocational education and training (TVET) institutes in skills development and technology-sourcing for MSEs (FDRE, 2011).

The First Growth and Transformation Plan of the country, implemented during the period 2010-11 to 2014-15, brought some changes in the MSE sector through skills development and promotion of entrepreneurship (MoFED, 2010). The Second Growth and Transformation Plan (GTP II), which is currently under implementation and runs from 2015-16-2019-20, points to the critical role of MSEs in employment generation, promotion of entrepreneurship, and broadening the base for value addition in the domestic private sector (NPC, 2015). The country's Industrial Development Strategy, and Science, Technology and Innovation Policy, stress the need for strengthening MSEs to enhance their role in industrial development (FDRE, 2002; 2012).

The government has established several organisations mandated to support MSE development, including: the aforementioned FeMSEDA, the Regional Micro and Small Enterprises Development Agencies (ReMSEDAs), and the Handicrafts and Small-Scale Industries Development Agency. National development agencies and international organisations are also actively involved in provision of basic business skills training to Ethiopian MSE operators (Debela, 2015; UNDP, 2015).

\section{MSEs'buman capital}

MSEs in Ethiopia are mostly family-owned, and are characterised by low levels of human capital, which undermines their capacity for technological absorption and innovation (Belete, 2015). According to a survey conducted by the Ethiopian Ministry of Urban Development and Construction in 2013,33\% of the owners of 3,000 MSEs 
included in the survey had attended only primary-level education (MUDC, 2013). A 2010 report by the Ministry of Education showed the shortage of trained manpower in Ethiopia, finding that, in 2009, the net enrollment rate for secondary education in the country was only $12.6 \%$, while the total number of students enrolled in TVET institutes was only 717,603 (MOE, 2010). It is not common for Ethiopian MSEs to invest in formal training of their employees. In most informal-sector MSEs, as the research findings outlined below will confirm, the workers get their skills through engagement in daily work processes and interaction with more experienced workers. The training normally takes place through working alongside a skilled worker, observing his or her work, and gradually taking over the job.

\section{MSEs'access to finance}

According to a report by the World Bank (2015), financing is perceived as the main business constraint by $41 \%$ of micro, and $36 \%$ of small, enterprises in Ethiopia, compared to Sub-Saharan African averages of $24 \%$ and $20 \%$ respectively. It has been found that Ethiopian MSEs typically have no external financing, as a result of either being rejected for loans or not even applying due to terms and conditions that cannot be met (World Bank, 2015). The existing financial system of the country is not designed in a way that addresses the needs of MSEs (MOST, 2010).For many small businesses, the personal funds of the founders, and of their families and friends, represent the key source of finance at the start-up stage of enterprises. These funds are often insufficient to cover the needs of the enterprises as they expand and show increasing promise, severely constraining enterprise growth (Carpenter \&Peterson, 2002).

\section{Lack of incentive schemes}

There are no targeted incentives for the promotion of innovation in Ethiopian MSEs. However, Ethiopia's Investment Incentives Regulation (FDRE, 2014) provides exemptions from customs duty for imports of machinery, equipment and accessories used in workshops and laboratories. This presumably has a positive effect on the cost of technology acquisition by certain MSEs. Furthermore, the Investment Incentives Regulation provides exemptions from income tax for limited periods of time for investors in certain targeted areas of manufacturing, which may encourage some MSEs to invest in new technology.

\section{Entrepreneurship support}

Ethiopia has a long history of entrepreneurship, dating back to the medieval and mercantile eras. However, until recent years, there was a lack of comprehensive entrepreneurship support to MSEs in Ethiopia, with interventions limited to training programmes (UNDP, 2015). In recognition of this gap, there have been some recent initiatives aimed at developing MSE entrepreneurship. One such initiative, running since 2013, is the Entrepreneurship Support Programme, a joint project by the United Nations Development Programme (UNDP) and the Ethiopian Government. 
The project supports the building of entrepreneurial skills and mindsets within MSEs, particularly women and youth, and supports the government's efforts to establish training and service institutions and financial support for entrepreneurship (UNDP, 2015; n.d.).The government has also initiated a Women Entrepreneurship Development Project, with World Bank support, that aims to increase the earnings and employment of women in urban areas through tailored financial instruments, developing women's entrepreneurial skills, and supporting cluster, technology and product development (FeMSEDA, 2012).

\section{MSEs' linkage with technology development organisations, educational institutes}

The Government of Ethiopia has set up Technology Institutes in selected sectorssuch as textiles, leather, metals, engineering and agro-processing - that are responsible for technology acquisitions and transfer in their respective industries. Moreover, the country's TVETs are expected, in terms of the state TVET Strategy (MOE, 2008), to transfer technologies to MSEs in order to, among other things, increase their productivity and improve the quality of their products and services. However, due to lack of the required capacity on the part of the TVETs, and weak TVETMSE linkages, TVETs have not been able to adequately fulfill their MSE support mandates. Collaboration between MSEs and the Technology Institutes is also weak (MOST, 2013).

\section{The Shiro Meda and Merkato MSE clusters}

The two small-enterprise clusters studied, the Shiro Meda and Merkato enterprise clusters in Addis Ababa, both spontaneously developed over long periods of time. In the Shiro Meda handloom-weavers cluster, there is a large concentration of weavers who originally came from southern Ethiopia. It has been estimated that there are more than 20,000 handloom-weavers in Addis Ababa's Gulele subcity, the subcity of which Shiro Meda is part (Ali, 2007). In the 19th century, when Ethiopia was ruled by Emperor Menelik, a large number of weavers, mainly from the Dorze ethnic group of Gamo Highlands in the south, came to Addis Ababa and settled at the foot of Entoto Mountain, where the Shiro Meda cluster is situated. These people, who were skilled in the art of weaving, became the major producers of traditional clothes for the city's dwellers. Nowadays people use the term "Dorze" to refer to both the weaving community and to all the people who originally came from the Gamo Highlands (Prouty \& Rosenfeld, 1981).

Although there are weavers in different parts of Addis Ababa who come from other ethnic groups, the Dorze weavers from the Gamo Highlands dominate the field. There are numerous shops for traditional textiles located in Shiro Meda. The streets are lined with small stores selling different varieties of traditional Ethiopian clothes. The neighborhood is identified with weaving and is considered by many people in Addis Ababa as a major shopping centre for traditional clothes. 
The other cluster, the Merkato shoemaking cluster, is - based on my observations and on unofficial estimates communicated to me-home to around 5,000 MSEs engaged in either manufacturing or repairing leather footwear. Most of the enterprise owners and employees in the cluster come from the Gurage ethnic group. Suppliers of inputs, and other service providers for the footwear manufacturers, are also located in the cluster. Therefore, the shoe producers in the cluster buy their raw materials, labour supplies, and other services - such as machinery and equipment maintenance, and design services-from within the cluster. The MSEs sell their products through the wholesalers that are located around the cluster. These wholesalers then distribute the shoes to the Merkato retail shops and elsewhere. The Merkato shoe manufacturers interviewed for this study were located in a part of Merkato known as "Shera Tera".

As alluded to above in the "Methodology" sub-section, the two clusters experience different competitive environments. The MSEs in the Merkato footwear cluster face competition from medium- and large-scale footwear manufacturing enterprises outside the cluster, and run by educated entrepreneurs, which frequently introduce new product designs and use modern production methods and marketing strategies. There are also imported shoes made available in the domestic market, competing with the Merkato shoemakers' products.

In contrast, the MSEs in the Shiro Meda handloom-weaving cluster operate in the absence of a strongly competitive environment. While there are a few modern fashion designers, operating outside the cluster, who started their businesses inspired by the traditional designs of the weavers, these designers tend to be collaborators with, rather than competitors to, the Shiro Meda weavers. The fashion designers procure from the weavers, relying on the weavers for certain fabrics and embroidery skills.

\section{Findings and analysis}

\section{Size and age of the MSEs}

In the Shiro Meda cluster, the number of people working in the weaving enterprises studied ranged between two and four. The oldest weaving enterprise included in the study was 33 years old, while the youngest enterprise was eight years old, its owner having completed his apprenticeship with another enterprise in the cluster and then become an independent weaver.

In the Merkato footwear cluster, of the 14 shoemakers interviewed, 10 were owners of enterprises while the remaining four were employees. The smallest enterprise was operated only by the owner, while the three largest enterprises had six employees each. The shoemaking MSEs ranged in age from 19 years to five years. 


\section{Financing}

In the Shiro Meda weaving cluster, the owners of the studied enterprises had all obtained their financing from informal sources. Sixteen of the interviewees had started their businesses with money obtained and/or borrowed from their fathers and other relatives. The remaining five had used savings from the small amounts of money they had earned while serving as apprentices to senior weavers. They had used their savings to acquire the materials required to start their own weaving businesses.

Meanwhile, the main source of capital for expansion of the weaving enterprises was found to be rotating funds, known as an "iqubs", established by small groups of people. In Ethiopia, iqubs are important sources of finance for people who do not have access to credit from formal financial institutions, allowing members to save for when they need to make large cash outlays. Each week or month, members of an iqub contribute a specified amount of money, and the total money collected is then given to one of the collective's members. This continues until each member is paid the amount equivalent to his total contribution. None of the Shiro Meda interviewees had secured access to financial services from banks or micro-finance institutions.

In the Merkato shoemaking cluster, the main sources of finance-for all of the interviewees - for starting and expanding their businesses, was money obtained from family members and their own savings. Due to their informality, the enterprises cannot fulfill the requirements necessary to get loans from financial institutions.

\section{Choice of business location}

In the Shiro Meda weaving cluster, all 21 of the weavers who were interviewed, when asked for their reasons for starting their businesses in the cluster, gave more or less the same reasons. The major reason was that Shiro Meda is a place where people from the weavers' ethnic group, the Dorze people—including their fathers and other family members - had already located their businesses. Being close to their relatives and people from the same ethnic group was said to have special value to the weavers. They said they interact with the Dorze community members in various ways that directly or indirectly benefit their work and their family lives. In addition, a large number of input suppliers, and shops which sell traditional clothes, are located in Shiro Meda. The weavers said they buy most of the materials they need in their production processes from within the cluster, near their working areas.

In the Merkato cluster, the shoe manufacturers interviewed explained that they had located their businesses in Merkato because they wanted to be close to other shoemanufacturing friends and family members, who had started their businesses before them in that same cluster. As additional reasons, they mentioned proximity to input suppliers and proximity to wholesale and retail shoe shops. 


\section{Products}

The main products of the Shiro Meda handloom-weavers are fabrics used to make the elements that go into women's and men's traditional Ethiopian national dress, the yehabesha libis. The weavers make fabrics for the women's traditional dresses, for the netela (a white scarf worn by women), for men's waistcoats, and for gabi-the heavy white wrap used by both men and women to protect themselves from the cold. The handwoven fabrics are also used for household products such as blankets, cushion covers, tablecloths, and window curtains.

The dresses made by the weavers are usually decorated with colorful embroidery called "tibeb". The weavers said they target the needs of people of different income levels. They seek to satisfy the demands of the middle- and high-income urban dwellers (who can afford higher-quality fabrics), while at the same time also supplying products, made of lower-quality fabric, that are affordable to lower-income groups in the city. To a certain extent, their products are also exported abroad to meet demand from Ethiopians in the diaspora.

It was found in the interviews that local demand for these handwoven traditional costumes is not at present being undermined by imported, factory-produced imitations. The weavers interviewed said that although the prices of the imported imitations are cheaper, customers prefer the locally produced, handwoven productsdue, to a great extent, to the superior quality of the weavers' handwoven fabrics and the special appearance of the weavers' embroidery. Traditional clothes have deep meaning for Ethiopians, and this has helped keep the attachment to handwoven goods alive. The ecclesiastical dresses worn by priests of the Ethiopian Orthodox Church are products of handloom-weavers. Many Ethiopians also appear in religious festivals, weddings, funerals and other occasions dressed in traditional costumes. The way the netela (scarf) is worn changes according to the occasion. When a woman is going to church, the netela is opened up and the pattern lies on both shoulders. For funerals, as a sign of mourning, the netela is worn with the patterned end to the face. In casual contexts, the pattern is worn over the left shoulder.

In the Merkato footwear cluster, the main product of the enterprises studied is men's leather footwear. Except for a few cases, the uppers and inside lining material of the men's shoes produced are 100\% pure leather. In the case of women's and children's shoes, it is common to use synthetic-leather components.

\section{Production processes}

In the Shiro Meda cluster, the weavers use traditional treadle handlooms. Weft threads are wound onto a bobbin (spindle) which is then put into a shuttle. The warp on the treadle loom is lifted by foot pedals which lift each of the shafts. Threads of 
the warp are alternately selected by hand to be lifted and lowered while the weft is passed between the threads with the shuttle. Traditionally, the weaving equipment was constructed from local materials such as eucalyptus and bamboo. Recently, however, some government institutions have introduced handlooms with metallic frames, and many weavers now use these metallic-frame handlooms, which are easy to dismantle, reassemble, and move from place to place. In the metal-framed looms, there are some improvements in how the shuttle works. However, the main technical features of the handloom have remained unchanged for generations.

The main raw material used by the Shiro Meda weavers, traditionally and today, is cotton yarn, both locally produced and imported. For embroidery, the weavers tend to also use silk, rayon, acrylic and wool yarn. Machine-spun cotton is often used both for warp and weft, but at the same time it is still common for handspun cotton to be used for weft. (Women clean the cotton from the seeds and rub the cotton with their fingers to pick out the seeds. Then they spin the cleaned cotton to make a weft.) The weavers complained that, in many cases, the quality of cotton in the market is sub-standard, which reduces the quality of fabrics they produce. In order to produce good-quality fabrics, a weaver thus needs to have knowledge of how to select goodquality cotton.

In the Merkato shoemaking cluster, the main pieces of equipment used are stitching machines, mechanical presses, grinders, skiving (cutting) machines, and shoe lasts. Most of these tend to be second-hand. It was found during the interviews that, due to financial constraints, the enterprises studied could not purchase all of the required machinery when they started their businesses, even if there were local suppliers of second-hand equipment in their vicinities. Only gradually, over time, did they manage to equip their workshops with the basic equipment required. For two of the interviewees, it took more than a decade to acquire the machinery they use today. They started their enterprises with minimal machinery, and depended on leased machines or outsourcing of work. The additional machines they acquired over the years have helped them to improve product quality and reduce production costs, thereby enhancing their market competitiveness.

The Merkato cluster shoemakers were found to use the services of modifiers of shoe "lasts": foot-shaped pieces of wood or metal. Modifiers give old lasts new shapes in order to produce new shoe designs. The lasts are adjusted by grinding their surfaces to modify them into the shape of the intended new shoe design. These modifications help the footwear producers to forego the cost of acquiring new lasts.

The shoemakers use both locally made and imported raw materials. The rubber soles, and leather used for upper parts and lining, are supplied by local producers, while 
such materials as PVC soles, adhesives, and eyelets are imported from abroad. Retail shops located in the Merkato cluster make these materials available.

The use of high-quality raw materials was reported by the shoemaker interviewees to be one of the major factors in improvement of the quality (i.e., durability, in the eyes of most consumers) of shoes produced. The main inputs in leather shoe-manufacturing are hides and skins, which are acquired from local sources. The quality of this local leather was, in the past, often sub-standard, due to poor animal husbandry practices, lack of adequate slaughter facilities, poor post-slaughter preservation, and poor handling, tanning and processing techniques (MOA, 2013).

The interviewees said that in recent years there have been some improvements in the quality of leather available in the market. According to the respondents, if one has knowledge of how to carefully inspect the leather raw material, it is possible to get high-quality inputs and thus produce good-quality outputs. (In recent years, the quality of shoes produced in Ethiopia has shown improvement sufficient to improve export and trade with some European countries and the US. For example, between 2011 and 2012, Ethiopian shoe exports through the African Growth and Opportunity Act (AGOA) increased more than tenfold-from USD630,000 to nearly USD7 million (USAID, 2014).)

Thus, in both clusters, it was found that knowledge of how to evaluate the quality of input raw materials is centrally important to the competitive advantage and success of enterprises.

\section{Education and learning}

It was found that almost all of the weavers interviewed in the Shiro Meda cluster learned the skill of weaving as young boys, from their fathers, immediate family members, or friends and acquaintances of their families. The vast majority learned directly from their fathers. In the words of interviewee 4 (2016):

I started learning the technique of weaving when I was 10 years old. I used to sit next to my father and was watching every step in the weaving process. I also helped out with winding the bobbins. Then I learned counting the threads for different types of cloths. (interviewee 4,2016)

Nowadays, however, it would appear that many weavers have decreasing interest in teaching their own sons the skill of weaving. The weavers interviewed said they want their sons to pursue their formal education and start work in professions, as they view weaving as an insufficiently profitable line of work. They complained that too high a proportion of the price paid by the final consumers is retained by shop-owners, dressmakers, and others in the fashion business. 
But there was one interviewee, a young weaver, who was optimistic about business possibilities based on traditional weaving, though with elements of modernisation and via a connection to a training institute and a successful designer:

My friend is studying fashion design in a private institute run by a known female designer. His ambition is to expand his business and get more young customers by giving a modern touch to his work. He insists that I should also join the institute so that we will be partners in the business. (interviewee 18, 2017)

The non-codified, informal, tacit knowledge that the weavers gain through experience was seen as the most valuable asset of the enterprises. Experienced weavers have good understanding of how every step in the weaving process determines the characteristics of the final product. From weaving lower-grade coarse cloth, to producing a range of medium-quality and fine fabrics, a great variety of cloths can be produced on the handlooms. The best-quality weaving produces dense and smooth fabric. According to interviewee 8 (2016):

My weaving skill has shown a significant improvement over the years. If you compare my work with those of junior weavers, you can see a big difference. When I was a young weaver, the netelas I made were very coarse and it was difficult for me to sell some of them. But now I can easily sell my netelas and gabis and the customers admire the quality of the fabrics I make and the attractiveness of the patterns. (interviewee 8, 2016)

Six of the 21 weavers included in the study said they had never attended formal education, i.e., they had no exposure to codified, formalised, explicit knowledge of weaving or related skills. However, all six had learned how to read and write through their own efforts. Eleven of the interviewees had between two and six years of schooling. One of the interviewees was an extension student at a TVET institute. Three were pursuing their high school education via night school and distancelearning programmes.

The relatively better-educated weavers were found to have more innovative and entrepreneurial tendencies. They were found to be taking various measures to differentiate themselves, through introducing product or market innovations. For instance, the interviewee attending a TVET institute, and the three who were taking steps to complete high school, were found to be more active than the other 17 lesseducated weavers in experimenting with non-cotton yarns such as rayon and acrylic.

These four better-educated interviewees were also found to be introducing new designs (e.g., to target young consumers) more frequently than the other 17 weavers. 
In the Merkato footwear cluster, it was found that the ways in which knowledge is shared and imparted has similar features to those in the Shiro Meda weaving cluster. All of the shoemakers interviewed said they acquired their knowledge of shoemaking from their parents and/or through apprenticeships with people connected to their families. Only one of the interviewees had received formal training: a short-term course in shoemaking, after he started his business, from the government-run Leather and Leather Products Technology Institute (since re-named the Leather Industry Development Institute).

The lowest duration of schooling among the shoemaker interviewees was eight years, and the highest qualification was a diploma from a TVET institute. A common view among the interviewees was that there is a relationship between enhanced performance of MSEs and the level of schooling/training received by the owners. According to interviewee 27 (2017):

I have a cousin who started the business much later than I did. However, his volume of production is much higher than mine and his products are of better quality. We admire him for his excellent marketing skills. All this is because of his higher level of education than many of us who operate in this area. (interviewee 27,2017)

\section{Business interactions and knowledge-sharing}

It was found that the interactions of the Shiro Meda weavers amongst themselves, with middlemen, with shop-owners, and with input suppliers, facilitates the sharing of information on markets for traditional clothes; sources of good-quality inputs; and sources of well-priced inputs. The weavers said that Sundays and Mondays are the days when they have the most opportunity to interact amongst themselves, either in the marketplaces or in other areas where they socialise. During these times, the subjects of discussion range from the family lives of the weavers to information on markets for both procuring raw materials and selling final products. In the words of interviewee 9 (2016):

When I meet my friends in places where we gather for local drinks, we exchange information about our work. This includes weaving techniques, suppliers of good quality cotton, thread and other inputs. I always share information with my relatives and close friends on these issues. (interviewee $9,2016)$

The weavers interviewed appeared to share an understanding that whatever competitive advantage they have over weavers in other clusters rests to a great extent on their non-codified, experience-based, tacit knowledge- and that there is significant power in deciding with whom to share this valuable knowledge. It was found that they clearly favour sharing of their knowledge and skills with apprentices, 
close relatives, and others with whom they have close social ties. As mentioned above, the weavers in the cluster predominantly belong to a single ethnic group, the Dorze - an element facilitating forging of social ties.

None of the weavers interviewed had exclusivity agreements with dressmakers or other dealers of traditional clothes (though it was said that other weavers, not among the interviewees, had such agreements). The weavers included in this study said they sell their fabrics to middlemen; to shop-owners; and, every Sunday at the open market in Shiro Meda, directly to final consumers. Only interviewee 18 (2017) spoke of receiving orders, and only very occasionally, from dressmakers. There are some Ethiopian retailers of traditional hand woven clothes who sell via websites, but none of the interviewees had received an order from an online retailer.

In the Merkato footwear cluster, it was found that there is stiff competition among the shoemakers - a much more competitive environment than that in the Shiro Meda weaving cluster. It was found that a large number of shoemakers compete in the same market, forcing them to use various tools to try to win customers. It was found that this high level of competition limits the sharing of knowledge and exchange of information between the MSEs in the cluster. And unlike in the case of the Shiro Meda weavers, ethnic-solidarity dimensions were not found to facilitate collaboration and knowledge-sharing (as stated above, most of the Merkato cluster's shoemakers are from the Gurage ethnic group). Instead, it was found that the shoemakers rely to a great extent on collaboration with the suppliers of inputs, and with their clients (retailers and wholesalers). For instance, it was found that the MSEs tend to have long-term relationships, based on trust, with retailers and wholesalers. The interviewees said they typically do not receive full outright payment from the retailer or wholesaler when they deliver the shoes, mostly receiving partial payments on delivery and collecting the balance after sales have been made.

Another form of interaction found to be important in the Merkato shoemaking cluster is that between the MSEs and the providers of technical services in the cluster. The relationships of the MSEs with last modifiers, skivers (who slice/scrape away edges), and repair and maintenance workers, was said to contribute to enhanced productivity and improved efficiency.

The cluster members were found to have very limited interaction with training institutes and technology development centers. As noted above, only one of the interviewees of this study benefited from a training programme offered by a government institute (the Leather Industry Development Institute).

(As mentioned above, in some cases, the medium- and large-scale footwear manufacturers subcontract production to small and micro units in Merkato. There is a mutual benefit in such arrangements. The subcontractors reduce their production 
costs while the MSEs benefit from utilisation of their production capacity, particularly in low-market seasons. Subcontracting can also reduce the capacity-building period needed for SMEs to develop: the desired levels of product quality and design; the ability to meet stated delivery times; and their ongoing innovation and differentiation capabilities (Ogot, 2012). Various well-known shoe brands in Ethiopia are produced by the MSEs in the Merkato cluster through subcontracting. However, it is only a very limited number of enterprises that have managed to get into this network and benefit from such subcontracting activities. None of the enterprises included in this study were found to be benefitting from such subcontracting arrangements.)

\section{Design innovations}

Among the interviewees in the Shiro Meda weaving cluster, it was found that innovation in design is widespread and is seen as constituting a means of securing decisive comparative advantage over competitors. Silk, rayon, acrylic and wool yarns are used for making the aforementioned tibeb (embroidery designs). Dresses may be embroidered around the collar, on the sleeves, on the hems, and on the front. The traditional netelas (scarves) for women have bands of multicoloured designs on the edges (see Figure 1 below). The traditional waistcoats for men are also decorated with embroidery, and some decorations are also used on the ends of the aforementioned gabi (wrap).Embroidery is also used on bed covers, pillow covers, tablecloths, and window curtains.

\section{Figure 1: Embroidery designs on netelas in the Shiro Meda cluster}

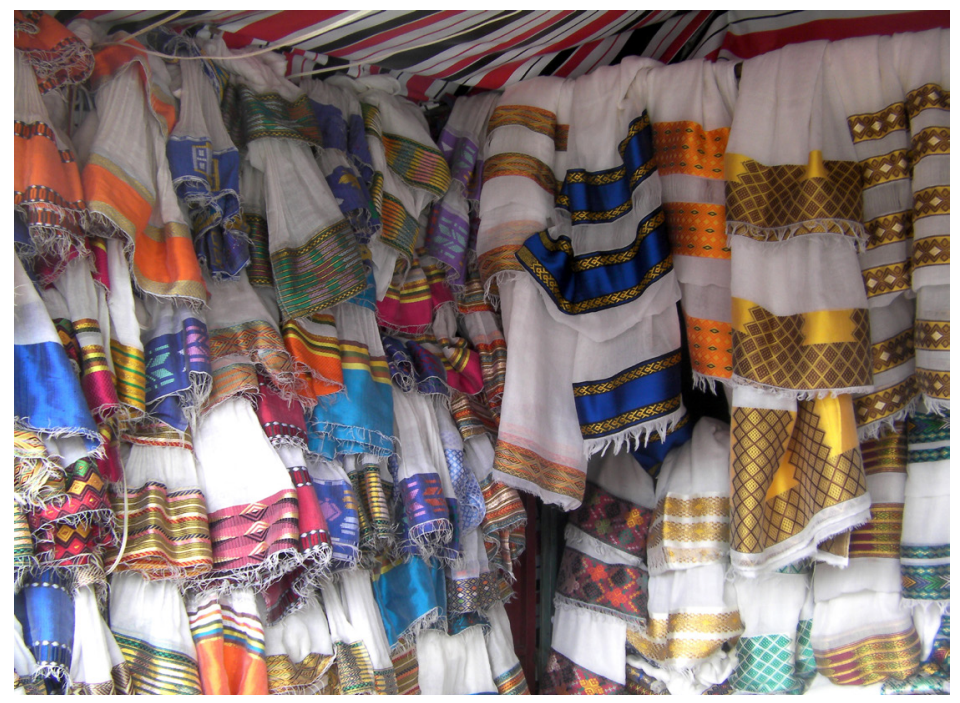

Source: Author fieldwork, 2017

Photo: Wondwossen Belete 
The weaver interviewees said they believed that one must know many embroidery designs in order to be competitive and stay in business, and that creation of new patterns and color combinations requires special skills. Although there are some common designs, there is no limit to the kinds of designs that can be created by the weavers. And it was felt that the intricate designs, resulting from the creative talents of the weavers, cannot be replicated by modern textile factories, i.e., the aesthetic value and quality of the power-loom sector's imitations of Ethiopian traditional costumes are not comparable to the products of the handloom sector.

Design is also an important source of competitiveness in the Merkato shoemaking cluster. It was found that there are freelance designers in the cluster who provide new shoe designs to the MSE manufacturers. In most cases, the designs are copies of imported shoe designs, which are new to the local context. In some cases, the designers also use their own talents to create new designs. The one interviewee who had received short-term formal training in shoemaking from the Leather Industry Development Institute was found to be using both his own designs and the designs of freelance designers in order to increase the range of shoe types he produces. $\mathrm{He}$ said that even if he produces shoes which are comfortable and durable, the young customers will not be interested in them unless they are in the latest styles.

Interviewees stated that the costs associated with the introduction of new designs arise not only from the payments to freelance designers but also from investment in an increased number of shoe lasts. Although many styles of shoe can be made on the same last, it is still necessary to increase the number of lasts to produce shoes with different toe shapes. This means additional investment by the shoemakers, either for acquisition of new shoe lasts or modifications of existing ones.

\section{Knowledge appropriation}

There is a large body of literature on the use of formal IP rights and other forms of knowledge appropriation, including informal-appropriation approaches, by developed-world, formal-sector enterprises. In contrast there is much less literature on knowledge appropriation modalities deployed by developing-world, informalsector MSEs. It is only recently that scholars have started addressing this area. De Beer, Fu and Wunsch-Vincent (2013), in their review of existing concepts, metrics and policies relevant to interrogating innovation and IP in the informal sector, outline a range of mechanisms for appropriation of benefits from informal-sector innovation. And studies by Essegbey, Awuni, Essegbey, Akuffobea and Micah (2014), Bull, Daniel, Kinyanjui and Hazeltine (2014), and Kraemer-Mbula and Tau (2014), have explored use of various knowledge appropriation tools in the informal-economy contexts of, respectively, herbal medicines in Ghana, metal manufacturing in Kenya, and manufacture of homecare and beauty products in South Africa. 
At the core of Ethiopia's IP system is its 1995 Proclamation Concerning Inventions, Minor Inventions and Industrial Designs (TGE, 1995). In a provision potentially favourable to MSEs, the 1995 Proclamation provides for utility model protection, whereby minor inventions that would not be patentable can be protected by a utility model certificate provided that the invention is(1) new in Ethiopia, and (2) has industrial applicability. Both product and process improvements qualify for utility model protection in Ethiopia.

Another type of formal IP protection provided for by the1995 Proclamation that is potentially relevant to MSEs is industrial design protection for the ornamental or aesthetic aspect of products. According to one of the patent administrators interviewed at the EIPO for this research, there have been numerous industrial design registration applications for designs used in Ethiopian traditional clothing, but none from traditional weavers of the sort working at the Shiro Meda cluster. According to the EIPO interviewee:

Among the applications we received for industrial design registration, 19 of them are for the protection of new patterns of traditional Ethiopian clothes. However, none of the applications are filed by traditional weavers. Fashion designers who have business relationships with the weavers filed most of the applications to get protection through registration. (interviewee $37,2017)$

(None of the Shiro Meda traditional weavers interviewed for this study spoke of supplying designs to fashion designers who had subsequently sought industrial design protection for the designs, but it is possible that some of the weavers' designs had been the subject of such applications. Some of the weavers said that they were aware of fashion designers seeking to use the formal IP tool of trademark protection to protect marks affixed to their products, as one of their market strategies.)

The weavers interviewed were found to rely on informal modes of knowledge appropriation in their efforts to maximise economic benefit from their innovative designs. For example, the weavers rely on lead time as a means of getting reward for their design innovations, i.e., the weavers enjoy competitive advantage until others copy the design. When asked whether they would ever seek to protect their designs through formalised industrial design registration, the weavers interviewed answered that they would be glad to use the opportunity. They stated that they would expend increased time and effort on design creation if there were a system which protected their designs from being easily copied by others. However, after they were briefed about the process that would need to be followed for formal IP protection of their designs, they became doubtful that they could effectively use the formal IP system, given the costs involved, the time-consuming examination process, and other associated bureaucratic issues. 
In the Merkato footwear cluster, it was said by the interviewees that some of the designs produced by freelance designers in the cluster had been registered at the EIPO. (Indeed, the footwear sector was found to be one of the major users of the formalised industrial design IP protection system in Ethiopia. A number of individual footwear designers, and shoe-manufacturing enterprises who employ the services of designers, have registered their designs at the EIPO.) According to the Merkato interviewees, copying of others' designs was, until recently, a common practice among designers. Nowadays, however, more and more designs are registered at the EIPO, with the effect of excluding others from producing shoes with similar designs.

(The law in Ethiopia requires that in order to get industrial design protection through registration, a design must be different from other designs known (1) in Ethiopia, and (2) abroad. However, in practice, when the EIPO Gazette publishes designs for which applications have been filed and invites statements of opposition against registration, the circulation of the Gazette is mainly in Ethiopia. Thus, only in rare cases does the EIPO receive statements of opposition from abroad, where many of the designs originate. Thus, in effect, novelty is judged only against designs already present in Ethiopia, making it easy for copies of foreign shoe designs to get industrial design protection in Ethiopia.)

Nevertheless, for the interviewed shoemakers, the predominant approaches to knowledge appropriation were found to be informal. Most of the shoemakers use their own distinctive marks to distinguish the shoes they produce from the products of others. A multitude of marks can be found on the shoes in the Merkato cluster, embossed on the leather uppers through use of a mechanical press, or fixed on the insole via prints on synthetic fabric or plastic. The Merkato shoemakers pointed out that they cannot seek to formally register their marks as trademarks because, as informal entities, they do not have business licences from the government-one of the requirements for filing a trademark registration application. The interviewees said that as long as they produce shoes with reasonable quality and contemporary-looking designs, the wholesalers and retailers were happy to market their products carrying their specific, non-trademarked marks. Meanwhile, because some of the larger, more formalised shoe enterprises connected to Merkato have managed to formally register trademarks, when the Merkato shoemaking MSEs receive production sub-contracts from these formalised entities, the shoemakers sometimes have to add the appropriate mark to the shoes before delivery. 


\section{Conclusions}

\section{Patterns of innovation}

The findings show that the studied MSEs engage in several modes of innovation which help them to improve their competitiveness and exploit opportunities in the market. The improvements they make in the quality of their products, and the appealing designs they create or imitate from foreign products, are manifestations of their innovativeness. Both product innovations and market innovations give the MSEs a competitive edge in the market and help them to sustain their businesses. Process innovations by the MSEs - in the form of, for instance, deployment of new machinery or modification of existing means of production-are also among the factors for improvement of the quality of the traditional clothes and footwear produced in the two clusters covered by this study.

\section{Patterns of knowledge}

The importance of informal training for innovativeness is most clearly seen in the Shiro Meda handloom-weaving cluster. Although most of the weavers in the cluster do not have long years of formal schooling, they benefit from informal knowledgeacquisition processes - through which they gain tacit knowledge - that are integrated with their day-to-day activities. Channels of knowledge transfer in the two MSE clusters studied are mainly established through social interactions and informal communication networks. Such informal interactions and networks have, in some cases, important roles in determining MSE innovation and growth.

While formalised IP protections-via registrations of industrial design and trademarks - are playing some role in the dynamics and activities of both clusters (particularly in the Merkato shoemaking cluster), the studied MSEs in both the clusters rely primarily on informal knowledge appropriation modalities, such as lead time and unregistered marks. The MSEs studied are among the smallest and leastformalised players in their respective product value chains, and thus they do not have the resources and levels of formalisation necessary to fruitfully participate in most elements of the formal IP system.

But at the same time, the informal MSEs studied do engage, to varying and shifting degrees, in service provision to much-more-formalised entities-evidence that supports the conceptualisation, cited near the beginning of this article (with reference to the work of De Beer et al., 2013; Kraemer-Mbula, 2016; ILO, 2002; Steel \& Snodgrass, 2008), of innovative informal-sector enterprises as operating at various, and shifting, points along a continuum between informality and formality.

\section{Relevance to policymaking}

The Ethiopian Government's policy approaches relevant to the MSE sector have not, to date, been characterised by a sufficiently holistic understanding of the challenges, needs and expectations of the enterprises and workers in the informal sector. An 
apparent lack of evidence-based analysis in support of policymaking has contributed to this disconnect between government policies and the realities of the informal sector. In designing policies to foster innovation and sustainability in Ethiopia's informal sector, there is a need, going forward, for clearer focus on the nature and dynamics of the MSEs that dominate this sector, of the processes of learning and innovation in these MSEs, and of interactions between these informal-sector MSEs and more-formalised entities.

\section{References}

Ali, M. (2007). The competitiveness and viability of cluster based cottage industries: The case of handloom sector in Ethiopia. Addis Ababa: Ethiopian Development Research Institute (EDRI) Working Paper Series.

Belete, W. (2015). Human capital barriers to technological absorption and innovation by Ethiopia's micro and small enterprises (MSEs).The African Journal of Information and Communication (AJIC), 16, 73-77. https://doi.org/10.23962/10539/19316

Belete, W. (2018). Determinants of innovative performance by Ethiopian informal-sector micro and small enterprises (MSEs). Open AIR Working Paper 13. University of Cape Town and University of Ottawa: Open African Innovation Research (Open AIR).

Bull, C., Daniel, S., Kinyanjui, M. N., \& Hazeltine, B. (2014). Country study on innovation, intellectual property and the informal economy: The informal metalworking sector in Nairobi. Geneva: World Intellectual Property Organisation.

Carpenter, R. E., \& Peterson, B. C. (2002). Is the growth of small firms constrained by internal finance? The Review of Economics and Statistics, 84(2), 298-309. https://doi.org/10.1162/003465302317411541

Chaminade, C., Lundvall, B.-A.,Vang -Lauridsen, J., \& Joseph, K. J. (2009). Innovation policies for development: Towards a systemic experience based approach.Paper presented at the 7th Globelics Conference, Dakar, 6-8 October.

Central Statistical Agency (CSA).(2003). Report on cottage/handicraft manufacturing industries survey. Addis Ababa.

CSA. (2014). Report on urban informal sector sample survey. Addis Ababa

De Beer, J., Kun, F., \& Wunsch-Vincent, S. (2013). The informal economy, innovation and intellectual property - Concepts, metrics and policy considerations. WIPO Economic Research Working Papers 10. Geneva: World Intellectual Property Organisation, Economics and Statistics Division.

Debela, K. (2015). Women in the development of micro and small enterprises to ensure sustainable development and food security. Addis Ababa City Administration, Micro and Small Enterprises Development Bureau.

Dosi, G., \&Nelson, R.R. (2010). Technical change and industrial dynamics as evolutionary processes. In B. H. Hall, \& N. Rosenberg (Eds.), Handbook of the economics of innovation. Amsterdam: Elsevier. https://doi.org/10.1016/s0169-7218(10)01003-8

Duki, A. (2006). Unleashing the potential of MSMEs in Ethiopia: Report of the diagnostic study of the Merkato leather footwear cluster. Addis Ababa: Cluster Development Program, UN Industrial Development Organisation (UNIDO). 
Essegbey, G. O., Awuni, S., Essegbey, I. T., Akuffobea, M., \& Micah, B. (2014). Country study on innovation, intellectual property and the informal economy: Traditional herbal medicine in Ghana. Geneva: World Intellectual Property Organisation.

Fagerberg, J., \& Verspagen, B. (2002). Technology-gaps, innovation-diffusion and transformation: An evolutionary interpretation. Research Policy, 31(8-9), 1291-1304. https://doi.org/10.1016/s0048-7333(02)00064-1

Federal Democratic Republic of Ethiopia (FDRE). (1997). Micro and Small Enterprises Development Strategy. Addis Ababa.

FDRE. (2002). Industrial Development Strategy. Addis Ababa (in Amharic).

FDRE. (2009). National Employment Policy and Strategy of Ethiopia. Addis Ababa.

FDRE. (2011). Micro and Small Enterprise Development Strategy, Provision Framework and Methods of Implementation. Addis Ababa.

FDRE. (2012). Science, Technology and Innovation (STI) Policy of Ethiopia. Addis Ababa.

FDRE. (2014).Investment Incentives and Investment Areas Reserved for Domestic Investors, Council of Ministers (Amendment) Regulation No. 312/2014. Addis Ababa.

Federal Micro and Small Enterprise Development Agency (FeMSEDA). (2012). Women entrepreneurship development project: Environmental and social management framework draft report. Addis Ababa.

Freeman, C. (1982). The economics of industrial innovation (2nd ed.). London: Frances Pinter.

International Labour Organisation (ILO).(2002). Decent work and the informal economy: Sixth item on the agenda. Report VI, 90th session of the International Labour Conference. Geneva.

Jeffrey, J. (2014, March 20). Ethiopia’s female fashion designers embrace tradition to boost sales. Inter Press Service (IPS). Retrieved from http://www.ipsnews.net/2014/03/ Ethiopians-female-fashion-designers-embrace-tradition-boost-business/

Kraemer-Mbula, E. (2016). Informal manufacturing of home and personal care products in South Africa. In E. Kraemer-Mbula, \& S. Wunsch-Vincent (Eds.), The informal economy in developing nations: Hidden engine of innovation? (pp.146-193). Cambridge, UK: Cambridge University Press. https://doi.org/10.1017/cbo9781316662076.009

Kraemer-Mbula, E., \& Tau, V. (2014). Country study on innovation, intellectual property and the informal economy: Informal manufacturers of home and personal care products in South Africa. Geneva: World Intellectual Property Organisation.

Ministry of Agriculture (MOA). (2013). Hides, skins and leather value chain vision and strategy for Ethiopia. Livestock Master Plan Background Paper. Addis Ababa.

Ministry of Education (MOE). (2008). National Technical and Vocational Education and Training (TVET) Strategy. Addis Ababa.

MOE. (2010). Education Sector Development Program IV (ESDP IV): Program Action Plan. Addis Ababa.

Ministry of Finance and Economic Development (MoFED). (2010). Growth and Transformation Plan (GTP), 2010/11-2014/15. Addis Ababa.

MoFED. (2013). Brief note on the 2005 (EFY) GDP estimates series: The major results of the 2005 GDP estimates. Addis Ababa. 
Ministry of Science and Technology (MOST). (2010). Green Paper on Science, Technology and Innovation Policy: Building Competitiveness through Innovation. Addis Ababa.

MOST. (2013). Procedural Directive for the Linkage of Education and Training, Research Institutes and Industries. Addis Ababa.

Ministry of Urban Development and Construction (MUDC). (2013). Survey on micro and small enterprises (MSEs) in selected major cities of Ethiopia. Addis Ababa. Retrieved from http://www.mwud.gov.et/c/document_library/get file?uuid=28a0fa5f-8689-4828-9244- 7187413fb248\&groupId=10136

National Planning Commission (NPC). (2015). Growth and Transformation Plan II (GTP II) 2015/16-2019/20. Addis Ababa.

Nega, F., \& Edris, H. (2016). Small and medium enterprise access to finance in Ethiopia: Synthesis of demand and supply. Horn Economic and Social Policy Institute (HESPI) Working Paper 01/16. Addis Ababa.

Ogot,M.M. (2012). A generic competitive business strategies typology for micro-enterprises. European Journal of Business and Management, 4(20), 98-109.

Prouty, C., \& Rosenfeld, E. (1981). Historical dictionary of Ethiopia. London: Scarecrow Press.

Steel, W. F., \& Snodgrass, D. (2008). Raising productivity and reducing risks of household enterprises: Diagnostic methodology framework. World Bank Africa Region Analysis on the Informal Economy. Washington, DC: World Bank

Transitional Government of Ethiopia (TGE). (1995). Proclamation Concerning Inventions, Minor Inventions and Industrial Designs, No. 123/1995. Addis Ababa.

UN Conference on Trade and Development (UNCTAD). (2007). The least developed countries report: Knowledge, technological learning and innovation for development. Geneva and New York.

UN Development Programme (UNDP). (2015). Unleashing the potential of MSEs: Through entrepreneurial skills training, business development services and access to finance. Updated version of 2013 document. Addis Ababa: UNDP Ethiopia: Entrepreneurship Development Programme.

UNDP. (n.d.). Entrepreneurship development programme. UNDP Ethiopia Retrieved from http://www.et.undp.org/content/ethiopia/en/home/projects/entrepreneurshipdevelopment-programme.html

UN Industrial Development Organisation (UNIDO). (2016). Networking small enterprises in Ethiopia's leather sector. UNIDO with Italian Agency for Development Cooperation. Retrieved from http://www.unido.org/sites/default/files/2016-04/CLUSTERS ethiopia_leather_sectorpdf_0.pdf

US Agency for International Development (USAID). (2014). AGOA in action: Stories from East Africa Trade Hub partners and beneficiaries. Nairobi: USAID East Africa Trade Hub.

Westphal, L. E., Dahlman, C., \& Kim, L. (1985). Reflections on the Republic of Korea's acquisition of technological capability. In N. Rosenberg, \& C. Frischtak (Eds.), International technology transfer: Concepts, measures and comparisons. New York: Pergamon.

World Bank. (2015). SME finance in Ethiopia: Addressing the missing middle challenge. Washington, DC. 


\section{Appendices}

\section{Interview guide - MSEs}

\section{General background}

Name of interviewee:

Place and date of birth:

Gender:

Address:

Education level:

\section{Information about the enterprise}

1. What are the products of your enterprise?

2. What is the main type of work you do in your enterprise?

3. When did you start this enterprise?

4. Why did you choose this activity from others?

5. Why is theenterprise located at its present site?

6. How much was the initial capital of the activity/enterprise?

7. What was the major source of this capital?

8. Is your enterprise registered with a government agency?

9. Does the enterprise maintain a formal book of accounts in accordance with government guidelines?

10. Do you have employees in your enterprise?

11. If yes, how many of them are permanent employees?

12. How many of the people working in your enterprise are unpaid?

13. What are the most difficult problems affecting the current operation of your activity/enterprise?

\section{Production methods and inputs}

14. What types of equipment does your enterprise use in the production process?

15. Does the enterprise own or rent the main equipment/machinery in use?

16. What is the main source of supply of machinery and equipment?

17. Have you recently acquired any new equipment?

18. Have you recently introduced changes in your production methods?

19. If the answer to the above question is yes, who developed these new production methods which you adopted?

20. What motivated you to introduce the new production methods?

21. Where do you procure/obtain most of your raw materials or intermediate inputs?

\section{Product characteristic and marketing}

22. Have you recently introduced new products or product designs?

23. Have you recently made any improvements of existing products?

24. If you have introduced new products or made improvements to existing ones, what motivated you to do so?

25. To whom doyousellyour product?

26. Are the products of your enterprise exported (directly or indirectly)?

27. Does the enterprise produce on advance order?

28. How much was the gross value of your sales/income last year? 


\section{Networking and collaboration}

29. Do you have access to external sources of knowledge and information?

30. If yes, how important are these external information sources to your enterprise's activities?

31. Does your enterprise have any interaction with universities, government research organisations and industry development institutes?

32. Did your enterprise collaborate with other micro and small enterprises, which operate in your field of activity, to address common challenges?

33. Do you have interactions with owners or employees of other enterprises to share ideas, information and best practices?

34. How did you acquire the skills you are applying in your job?

35. Have you had any vocational/technical training?

36. Have you ever participated in tailored trainings seeking to resolve problems regarding access to credit, procurement of raw materials, marketing, technological innovation, etc.?

\section{Intellectual property rights}

37. Do you think new knowledge and ideas should be privately owned or freely and openly shared with others?

38. Do you think appropriation of innovations has an impact on profitability of business?

39. Have any of your new products been imitated by other enterprises without your consent?

40. Have you ever shared any of your production methods with other producers?

41. Do you have knowledge of the intellectual property system?

42. If the answer to the above question is yes, have you taken any steps to legally protect your enterprise IPRs?

\section{Interview guide - government}

Name of government institute:

Name of interviewee:

Department/Directorate/Section of interviewee:

Position:

Address:

\section{General information about the institute}

1. Is the institute organised as a federal government agency or a regional government agency?

2. What are the major activities of the institute?

3. Who are the stakeholders of the institute's activities?

\section{Innovation support scheme}

4. Does your institute provide support to promote MSE innovation?

5. If your institute provides financial support to MSEs, what criteria are used to select the recipients of support?

6. If your institute provides training to MSEs owners/employees, please explain the areas of training?

7. Does your institute provide information on markets, buyers and technology to MSEs?

8. What advisory services are provided by your institute to MSEs? 


\section{Government policies}

9. What micro and small enterprise sector specific policies are in place in the country?

10. What are the priorities in terms of developing the innovation capacities of MSEs?

11. Do you think the country's development policies address the needs of MSEs?

12. How do you see the impact of government policies and regulations on the performance of MSEs in the informal sector?

\section{Scope and impact of MSE innovation in the country}

13. What are the types of innovative activities performed by MSEs in the country?

14. What are the major constraints to innovation activities of MSEs in Ethiopia?

15. What are the main barriers to collaboration between MSEsanduniversities/research organisations in the country?

16. What are the major constraints or barriers that particularly affect the dissemination of MSE innovation?

\section{Intellectual property rights}

17. Do you think the existing intellectual property system is, on its own, adequate to protect innovation by MSEs?

18. If your answer is yes, in your view which IP protection mechanisms are better suited to the needs of MSEs?

19. What are the main shortcomings in IP laws and regulations that affect the ability of MSEs to use the IP system effectively?

20. If you think the formal IP protection mechanism is not appropriate for the kinds of innovation by MSEs, whatalternative appropriation mechanisms do you see as suitable to protect MSE innovations? 